\title{
Recombinant sterol esterase from Ophiostoma piceae: an improved biocatalyst expressed in Pichia pastoris
}

\author{
Víctor Barba Cedillo ${ }^{1}$ Francisco J Plou² and María Jesús Martínez ${ }^{1 *}$
}

\begin{abstract}
Background: The ascomycete Ophiostoma piceae produces a sterol esterase (OPE) with high affinity towards $p$ nitrophenol, glycerol and sterol esters. Its hydrolytic activity on natural mixtures of triglycerides and sterol esters has been proposed for pitch biocontrol in paper industry since these compounds produce important economic losses during paper pulp manufacture.

Results: Recently, this enzyme has been heterologously expressed in the methylotrophic yeast Pichia pastoris, and the hydrolytic activity of the recombinant protein (OPE*) studied. After the initial screening of different clones expressing the enzyme, only one was selected for showing the highest production rate. Different culture conditions were tested to improve the expression of the recombinant enzyme. Complex media were better than minimal media for production, but in any case the levels of enzymatic activity were higher (7-fold in the best case) than those obtained from 0 . piceae. The purified enzyme had a molecular mass of $76 \mathrm{kDa}$, higher than that reported for the native enzyme under SDS-PAGE (60 kDa). Steady-state kinetic characterization of the recombinant protein showed improved catalytic efficiency for this enzyme as compared to the native one, for all the assayed substrates ( $p$-nitrophenol, glycerol, and cholesterol esters). Different causes for this were studied, as the increased glycosylation degree of the recombinant enzyme, their secondary structures or the oxidation of methionine residues. However, none of these could explain the improvements found in the recombinant protein. N-terminal sequencing of OPE* showed that two populations of this enzyme were expressed, having either 6 or 8 amino acid residues more than the native one. This fact affected the aggregation behaviour of the recombinant protein, as was corroborated by analytical ultracentrifugation, thus improving the catalytic efficiency of this enzyme.

Conclusion: P. pastoris resulted to be an optimum biofactory for the heterologous production of recombinant sterol esterase from $O$. piceae, yielding higher activity levels than those obtained with the saprophytic fungus. The enzyme showed improved kinetic parameters because of its modified N-terminus, which allowed changes in its aggregation behaviour, suggesting that its hydrophobicity has been modified.
\end{abstract}

Keywords: Ophiostoma piceae, Sterol esterase, Pichia pastoris, Catalytic efficiency, N-terminal, Aggregation behaviour

\section{Background}

Sterol esterases (EC 3.1.1.13) hydrolyze fatty acid esters of sterol and are widespread in nature, being the human cholesterol esterase one of the best studied among this group of enzymes [1-3]. However, those from microorganisms are the most used for biotechnological purposes since they can be produced in bulk at low cost. Some examples of these

\footnotetext{
* Correspondence: mjmartinez@cib.csic.es

${ }^{1}$ Centro de Investigaciones Biológicas (CIB), Spanish National Research

Council (CSIC), Ramiro de Maeztu 9, Madrid 28040, Spain

Full list of author information is available at the end of the article
}

are the esterases from the bacterium Pseudomonas aeruginosa [4] and the actinomycete Streptomyces [5,6], the enzymes LIP2 and LIP3 from the yeast Candida rugosa [7-14], or those from the filamentous fungi Melanocarpus albomyces [15] and Trichoderma sp. AS59 [16].

Most of them share a common structural backbone belonging to the structural superfamily of $\alpha / \beta$-hydrolases, like esterases and lipases, where residues responsible for its catalytic activity are highly conserved and form the socalled catalytic triad Ser-Asp/Glu-His [17], being the serine residue the nucleophile responsible for the beginning of

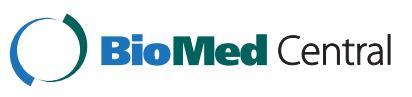


catalysis. For this reason, all these enzymes are also known as serine hydrolases.

They display a wide range of molecular mass, usually from 20 to $80 \mathrm{kDa}$, although enzymes with lower masses have been described, for example the $6.5 \mathrm{kDa}$ cholesterol esterase from Acinetobacter [18]. Typically, these proteins show tertiary structure but dimeric, tetrameric, and even hexameric forms or more can be found because of aggregation phenomena giving these pseudo-quaternary structures [6,19-21].

Their high versatility convert lipase-type enzymes in the most important group of biocatalysts in biotechnology, being used in different industries like food, detergent, pharmaceutical, leather, textile, cosmetic, and paper [22,23]. In fact, these enzymes accounted for about $5 \%$ of the world enzyme market in the year 2000 [24].

Recombinant DNA technology, together with protein engineering techniques, facilitates obtaining high quantities of an interesting enzyme at low cost, which allows the production of tailor-made biocatalysts [25]. Heterologous expression is a good approach for the production of these enzymes. Different prokaryotic and eukaryotic host systems can be used with this aim, although the advantage of the latest is its ability to carry out post-translational modifications, which can be very important to achieve the expression of a functional recombinant protein. This is the case of the methylothrophic yeasts, that provide a great potential as factories using methanol as the only carbon source [26]. The genera Hansenula, Pichia, Candida, and Torulopsis have been described as methylothrophic yeasts, but Pichia, and specially Pichia pastoris, is probably the most exploited yeast for recombinant protein production $[27,28]$. It is a consequence of the knowledge on the genetic characterization of this yeast gained during the last four decades, being a highly successful system for the production of a variety of heterologous proteins for the last 25 years [29]. This fact, and the advantage of having its genome sequenced [30], will contribute to facilitate recombinant expression and, inclusively, to improve it through systems biology strategies. Among the benefits of using $P$. pastoris as host system for heterologous expression are remarkable: i) its easy genetic manipulation and the stability of its transformants, thanks to the integration of the gene of interest by homologous recombination in its haploid genome, ii) its simplicity to be cultivated and to grow in minimal, and so inexpensive, media at high cell densities with low levels of endogenous protein secretion, together with the ability to efficiently secrete heterologous proteins, iii) fermentation processes are scalable to industrial levels of production, iv) different strong promoters are available to overexpress the gene of interest producing high quantities of protein, v) multiple copies of the gene of interest can be inserted into its genome, and vi) it also performs many of the higher eukaryotic post- translational modifications as protein folding, proteolytic processing, disulphide bond formation and glycosylation [31].

The sterol esterase from the saprophytic fungus Ophiostoma piceae (OPE) was previously characterized [32], and its possible application for pitch biocontrol during paper pulp manufacturing studied and patented because of its capability to hydrolyze triglycerides and sterol esters $[33,34]$. However, the use of any enzyme for biotechnological purposes requires making use of high quantities of protein. In a preliminary study [35], this enzyme was successfully expressed in P. pastoris (OPE*) and in this work we tackled the optimization of its production, studied its kinetic constants using $p$-nitrophenol, glycerol, and cholesterol esters, as well as analysed the cause of its improved catalytic properties.

\section{Material and methods Chemicals}

p-nitrophenyl butyrate and palmitate, glycerol esters, cholesterol esters, and polyoxyethylene 10 tridecyl ether (Genapol X-100) were purchased from Sigma. Triton X-100 (reduced form) was acquired from Fluka. All chemicals were of the purest available grade.

\section{Fungal strains and plasmids}

O. piceae (CECT 20416) was grown in modified CzapeckDox medium at $28^{\circ} \mathrm{C}$ and $160 \mathrm{rpm}$. E. coli DH5 $\alpha$ $\left(\right.$ Stratagene ${ }^{\circledR}$ ) was grown in Luria-Bertani medium at $37^{\circ} \mathrm{C}$ and $150 \mathrm{rpm}$, and used for cloning and plasmid amplification. P. pastoris GS115 (his4 auxotrophy) (Invitrogen ${ }^{\mathrm{mu}}$ ) was used as host strain for expressing the O. piceae mature esterase sequence under the transcriptional control of the $A O X 1$ promoter $\left(\mathrm{P}_{A O X 1}\right)$. The vectors pGEM-T Easy (Promega) and the shuttle vector pPIC9 (Invitrogen ${ }^{\mathrm{Tx}}$ ) were utilized for cloning and expressing the esterase gene, respectively.

\section{Plasmid and strain construction}

The mature $O$. piceae esterase sequence, harbouring $5^{\prime}$ EcoRI and 3' NotI sites previously incorporated by PCR, was cloned into the pGEM-T Easy vector, sequenced, and subcloned into the same sites of the pPIC9 vector. The construction was subjected to restriction analysis and sequenced to confirm the correct insertion and orientation of the mature esterase sequence. As a result, the OPE mature sequence was fused to the coding sequence of the $\alpha$-mating factor secretion signal prepropeptide for the extracellular release of the gene product. Transformation of Pichia spheroplasts with the SacI linearized recombinant vector pPIC9OPE, allowed isolation of $\mathrm{Mut}^{+}$phenotype transformants after homologous recombination of the vector within the $5^{\prime} A O X 1$ region in the yeast's genome. 
Oligonucleotides were synthesized by the Protein Chemistry facility at CIB. DNA sequencing was performed at SECUGEN.

\section{Culture conditions}

E. coli $\mathrm{DH} 5 \alpha$ was grown in Luria-Bertani medium $(10 \mathrm{~g} / \mathrm{L}$ tryptone, $10 \mathrm{~g} / \mathrm{L} \mathrm{NaCl}, 5 \mathrm{~g} / \mathrm{L}$ yeast extract, and $15 \mathrm{~g} / \mathrm{L}$ agar for solid medium) supplemented with 100 or $50 \mu \mathrm{g} / \mathrm{mL}$ ampicillin for liquid medium and agar plates, respectively. Bacteria were incubated at $37^{\circ} \mathrm{C}$ and $150 \mathrm{rpm}$ overnight.

P. pastoris $\mathrm{His}^{+} \mathrm{Mut}^{+}$transformants were screened for esterase activity in Petri dishes containing minimal methanol medium (MM) with tributyrin $(13.4 \mathrm{~g} / \mathrm{L}$ yeast nitrogen base without amino acids, $4 \times 10^{-4} \mathrm{~g} / \mathrm{L}$ biotin, $5 \mathrm{~g} / \mathrm{L}$ methanol, $1 \%$ tributyrin, and $15 \mathrm{~g} / \mathrm{L}$ agar). Plates were incubated during $48 \mathrm{~h}$ at $28^{\circ} \mathrm{C}$ and $100 \mu \mathrm{L}$ of pure methanol were added daily to the lid of the inverted plates. Positive clones were initially checked in $1 \mathrm{~L}$ Erlenmeyer flasks containing 100 or $200 \mathrm{~mL}$ of BMMY medium (described below).

The best $P$. pastoris transformant was grown in different culture media. i) buffered glycerol-complex/buffered methanol-complex media (BMGY/BMMY): $10 \mathrm{~g} / \mathrm{L}$ yeast extract, $20 \mathrm{~g} / \mathrm{L}$ peptone, $13.4 \mathrm{~g} / \mathrm{L}$ yeast nitrogen base without amino acids, $4 \times 10^{-4} \mathrm{~g} / \mathrm{L}$ biotin, $100 \mathrm{mM}$ potassium phosphate buffer $\mathrm{pH}$ 6.0, and $10 \mathrm{~g} / \mathrm{L}$ glycerol for BMGY medium and $5 \mathrm{~g} / \mathrm{L}$ methanol for BMMY medium, ii) buffered minimal glycerol/buffered minimal methanol media (BMG/BMM): same composition as BMGY/BMMY without yeast extract and peptone, iii) minimal glycerol/minimal methanol media (MGY/MM): $13.4 \mathrm{~g} / \mathrm{L}$ yeast nitrogen base without amino acids, $4 \times 10^{-4} \mathrm{~g} / \mathrm{L}$ biotin and $10 \mathrm{~g} / \mathrm{L}$ glycerol for MGY medium or $5 \mathrm{~g} / \mathrm{L}$ methanol for $\mathrm{MM}$ medium, and iv) buffered sorbitol-methanol- complex medium (YEPS): $10 \mathrm{~g} / \mathrm{L}$ yeast extract, $20 \mathrm{~g} / \mathrm{L}$ peptone, $10 \mathrm{~g} / \mathrm{L}$ sorbitol, $100 \mathrm{mM}$ potassium phosphate buffer $\mathrm{pH}$ 6.0, and $5 \mathrm{~g} / \mathrm{L}$ methanol.

A single colony from fresh yeast extract peptone dextrose (YPD) plates $(10 \mathrm{~g} / \mathrm{L}$ yeast extract, $20 \mathrm{~g} / \mathrm{L}$ peptone, $20 \mathrm{~g} / \mathrm{L}$ dextrose, and $20 \mathrm{~g} / \mathrm{L}$ agar) was used to inoculate $25 \mathrm{~mL}$ of BMGY, BMG or MGY media in $250 \mathrm{~mL}$ flasks, which were incubated overnight at $28^{\circ} \mathrm{C}$ and $275 \mathrm{rpm}$ until an optical density at $600 \mathrm{~nm}$ (O.D.600) value between 2-6 was reached. Then, cells were harvested by centrifugation and resuspended in $100 \mathrm{~mL}$ or $200 \mathrm{~mL}$ of BMMY, BMM or MM media to an O.D.600 of 1 , in $1 \mathrm{~L}$ Erlenmeyer flasks, following the Invitrogen's protocol [36]. YEPS medium was directly inoculated from a fresh single colony.

Media used for induction and expression were maintained at $28^{\circ} \mathrm{C}$ and $250 \mathrm{rpm}$ during at least $96 \mathrm{~h}$. In these media methanol was added daily at a final concentration of $5 \mathrm{~g} / \mathrm{L}$ for maintaining the induction and counteract evaporation.

\section{Enzyme assay, protein determination, and biomass measurement}

Enzyme activity was routinely measured by monitoring $p$-nitrophenol release from $1.5 \mathrm{mM} p$-nitrophenyl butyrate $(p \mathrm{NPB})$ in $20 \mathrm{mM}$ Tris- $\mathrm{HCl} \mathrm{pH} 7.0$ buffer at room temperature in a Shimadzu UV-160A spectrophotometer [32]. One unit of activity (1U) is defined as the amount of enzyme releasing $1 \mu \mathrm{mol}$ of $p$-nitrophenol $\left(\epsilon_{410}=15,200 \mathrm{M}^{-1}\right.$ $\mathrm{cm}^{-1}$ ) per minute under the defined conditions. $20 \mathrm{mM}$ citrate-phosphate-borate buffer was used for stability studies and optimum $\mathrm{pH}$ determination.

Protein concentration was determined by the Bradford microassay (BioRad) using bovine serum albumin as standard (Sigma).

$P$. pastoris biomass was expressed as measures of turbidity of the samples at O.D.600. This absorbance was correlated with the equivalent dry cell weight (DCW) in $\mathrm{g} / \mathrm{L}$ multiplying the observed absorbance value by a factor of 0.2 .

\section{Enzyme purification}

The native enzyme was purified from 15-day-old O. piceae cultures in modified Czapeck-Dox medium supplemented with $0.5 \%$ olive oil [32]. The recombinant protein was purified from 4-day-old cultures in YEPS medium. Cultures were centrifuged 30 minutes at 13,000 rpm and $4^{\circ} \mathrm{C}$, and filtered. Culture filtrates were concentrated by ultrafiltration using both a Millipore Pellicon ${ }^{\mathrm{Tm}}-2$ Miniholder, coupled with a Masterflex ${ }^{\circledR}$ pump, and an Amicon ${ }^{\circledR}$ devices, equipped with 5 and $3 \mathrm{kDa}$ cut-off membranes, respectively. $0.5 \mathrm{M}$ $\left(\mathrm{NH}_{4}\right)_{2} \mathrm{SO}_{4}$ was added to concentrated samples and these were applied to a HiTrap Octyl Sepharose FF Cartridge (GE Healthcare) previously equilibrated with $0.5 \mathrm{M}$ of the salt in $25 \mathrm{mM}$ Tris- $\mathrm{HCl}$ buffer $\mathrm{pH} 7.0$, by using an Akta HPLC system (GE Healthcare). Proteins were eluted with a linear decreasing gradient $(0.5-0 \mathrm{M})$ of $\left(\mathrm{NH}_{4}\right)_{2} \mathrm{SO}_{4}$ in the same buffer during 60 minutes and the sterol esterase, which remained bound to the gel at the end of the gradient, was released after addition of $0.2 \%(\mathrm{v} / \mathrm{v})$ reduced Triton $\mathrm{X}-100$ in milli-Q water. Fractions containing esterase activity were pooled, diluted below critical micellar concentration of Triton X-100 in $25 \mathrm{mM}$ sodium phosphate buffer $\mathrm{pH}$ 6.0, and concentrated again as mentioned above.

\section{Molecular mass determination}

Sodium dodecyl sulphate polyacrylamide gel electrophoresis (SDS-PAGE) was performed in a Mini-protean III unit (BioRad) using running gels at $7.5 \%$. N-linked-carbohydrate content (\%) was estimated by comparing the molecular mass of the native and the N-deglycosylated protein. Deglycosylation was done treating the thermally denatured esterase with $10 \mathrm{mU}$ of Endoglycosidase $\mathrm{H}$ (Roche) in $50 \mathrm{mM}$ acetate buffer $\mathrm{pH} 5.0$ with $0.06 \%$ (v/v) SDS and $0.1 \mathrm{mM}$ $\beta$-mercaptoethanol at $37^{\circ} \mathrm{C}$ overnight. Protein bands were 
visualized either with Coomassie R-250 or silver staining (depending on protein concentration).

The purified recombinant enzyme $(20 \mathrm{pmol} / \mu \mathrm{L})$ was analyzed by MALDI-TOF mass spectrometry. The protein was crystallized in a saturated matrix solution (sinapinic acid in $0.1 \%(\mathrm{v} / \mathrm{v})$ trifluoroacetic acid in a $1: 3$ acetonitrile:water solution). Desorption, ionization, and analysis of the sample was accomplished in an Autoflex III MALDI TOF/TOF instrument (Bruker Daltonics) equipped with smartbeam, and analyzed using the positive ion linear mode. Protein Calibration II (Bruker) ranging from 20 to $70 \mathrm{kDa}$ was used as external standard.

\section{Kinetic studies}

Catalytic parameters were obtained for different $p$-nitrophenol, glycerol, and cholesterol esters.

For these studies, the hydrolysis of $p \mathrm{NPB}$ and $p$-nitrophenyl palmitate $(p \mathrm{NPP})$ were assayed in $3 \mathrm{~mL}$ reactions containing $100 \mathrm{mM}$ sodium phosphate buffer $\mathrm{pH}$ 7.0, with $0.15 \mathrm{M} \mathrm{NaCl}$ and 1\% (v/v) Genapol X-100 using an Uvikon spectrophotometer with magnetic stirring and temperature control at $25^{\circ} \mathrm{C}$. One unit of activity $(1 \mathrm{U})$ is defined as the amount of enzyme releasing $1 \mu \mathrm{mol}$ of $p$-nitrophenol $\left(\epsilon_{410}=15,200 \mathrm{M}^{-1} \mathrm{~cm}^{-1}\right)$ per minute under the defined conditions.

The hydrolysis of glycerol and cholesterol esters was assayed titrimetrically in a pH-stat model DL50 (Mettler Toledo) using $0.1 \mathrm{~N} \mathrm{NaOH}$ as titrant at $25^{\circ} \mathrm{C}$ and $30 \%$ stirring rate. The reactions were carried out in $1 \mathrm{mM}$ Tris- $\mathrm{HCl}$ buffer $\mathrm{pH} 7.0$, with $0.15 \mathrm{M} \mathrm{NaCl}$ and $5 \%$ (v/v) Genapol X100 in a final volume of $20 \mathrm{~mL}$ containing the substrate, which was previously emulsified in the detergent. One unit of activity (1U) is defined as the amount of enzyme releasing $1 \mu \mathrm{mol}$ of free fatty acid per minute.

Experimental data were fitted to hyperbolic MichaelisMenten curves and statistically analyzed with Sigma Plot 11.0 software.

\section{Circular dichroism spectroscopy}

$200 \mu \mathrm{L}$ samples of both the native and recombinant proteins at $0.1 \mathrm{mg} / \mathrm{mL}$ in $25 \mathrm{mM}$ sodium phosphate buffer $\mathrm{pH} \quad 6.0$ were monitored using circular dichroism spectroscopy (CD) on a J-720 spectropolarimeter (Jasco), in $1 \mathrm{~mm}$ light path quartz cuvettes (HELLMA). Spectra were acquired in the amide band (195-260 nm) at room temperature at $20 \mathrm{~nm} / \mathrm{min}$, with $0.5 \mathrm{~nm}$ bandwidth and a $4 \mathrm{~s}$ time constant. The spectra were measured in quadruplicate, averaged, and baseline corrected by subtraction of a buffer blank. Far-UV CD spectra were analyzed on DichroWeb website, using the K2d algorithm [37].

\section{$\mathrm{N}$-terminal sequencing and amino acid composition}

$\mathrm{N}$-terminal sequence of the recombinant protein was obtained by automated Edman degradation of $10 \mu \mathrm{g}$ of purified sample using a Procise 494 instrument (Applied Biosystems).

Amino acid composition and potential amino acid modifications were determined, in duplicate, with a Biochrom 30 analyzer (Biochrom, UK) after hydrolyzing $10 \mu \mathrm{g}$ of native and recombinant sterol esterases with $6 \mathrm{~N} \mathrm{HCl}$ at $110^{\circ} \mathrm{C}$ during 24 hours in vacuum. Amino acids were separated by cationic exchange chromatography and derivatized with ninhydrin postcolumn. Norleucine was used as the internal standard and methionine sulfone (Sigma) as standard of protein oxidation.

\section{Analytical ultracentrifugation}

Analytical ultracentrifugation was used to compare the aggregation behaviour of both the native and recombinant proteins. Purified proteins $(200 \mu \mathrm{g} / \mathrm{mL})$ in $25 \mathrm{mM}$ sodium phosphate buffer, $\mathrm{pH} 7.0$, with and without $1 \%$ (v/v) Genapol X-100, were used for these experiments. Measurements were performed in a XL-A analytical ultracentrifuge (Beckman-Coulter Inc.) equipped with UV-VIS detection optics, using an An50Ti rotor. Protein concentration was estimated by absorbance. Results were analyzed with SEDFIT (version 11.8) and HeteroAnalysis (version 1.1.33) softwares for sedimentation velocity and equilibrium experiments, respectively.

\section{Results}

\section{Screening of esterase producing clones}

Twenty randomly picked $\mathrm{His}^{+}$transformants were checked for methanol utilization by plating onto MM and MD plates as previously reported [35]. All transformants presented a $\mathrm{Mut}^{+}$phenotype and exhibited hydrolytic halos on MM-tributyrin plates because of their ability to hydrolyze the triglyceride. Five transformants were selected and cultured in liquid media in Erlenmeyer flasks, in order to check their production levels.

\section{Production in Erlenmeyer flasks}

The five $\mathrm{His}^{+} \mathrm{Mut}^{+}$selected transformants were grown in 1L Erlenmeyer flasks containing 200 or $100 \mathrm{~mL}$ of BMMY medium. Differences regarding culture volume were found, showing better production in flasks with $100 \mathrm{~mL}$ of medium, between 3- and 7-fold increase in productivity depending on the colony, respect to the levels reached in flasks with $200 \mathrm{~mL}$.

The best transformant was selected to optimize esterase production using different culture media (Figure 1). Yields in buffered media (YEPS, BMMY, and BMM) were higher than in the unbuffered MM medium, where the activity was very low probably due to the drastic decrease in $\mathrm{pH}$ value (from $\mathrm{pH} 6.0$ to $\mathrm{pH} 2.0$ after 48 hours), which could affect enzyme activity. Complex media (YEPS and BMMY), with peptone and yeast extract, gave better yields than minimal media (BMM and 

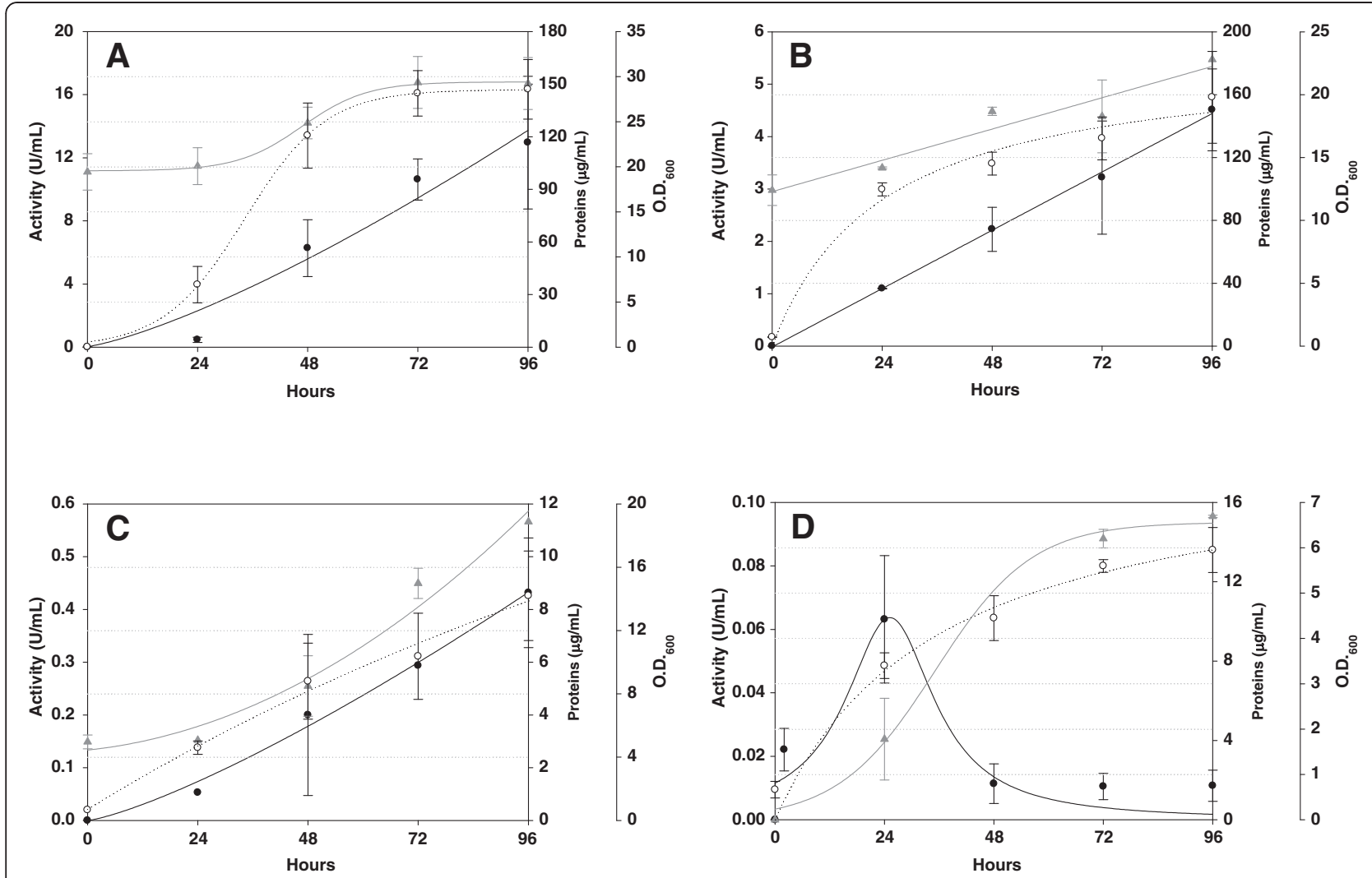

Figure 1 Production of recombinant sterol esterase from $\mathbf{O}$. piceae using different media. Heterologous production in YEPS buffered complex medium with sorbitol as co-substrate (A), BMMY buffered complex medium (B), BMM buffered minimal medium (C.), and MM minimal medium (D). U/mL vs pNPB (black circle); proteins $\mu \mathrm{g} / \mathrm{mL}$ (gray triangle); O.D. 600nm (white circle). Data points are the average of at least two different experiments. Error bars represent standard deviation. Data points were fitted to curves using Sigma plot 11.0 software.

MM). The addition of sorbitol as a second carbon source in YEPS medium was beneficial for the production. The sterol esterase activity levels in YEPS, BMMY, and BMM media, after $96 \mathrm{~h}$ of induction, turned out to be 7-, 2.5- and 0.2-fold higher than those got when $O$. piceae was cultured in modified Czapeck-Dox medium $(1.8 \mathrm{U} / \mathrm{mL})$ for 15 days [32]. The efficiency of $P$. pastoris cells on sterol esterase production in YEPS medium ( 2,266 U/g biomass), was 2-, 15-, and 127-fold higher than in BMMY, BMM, and MM media, respectively.

\section{Purification and biochemical characterization}

The recombinant protein was purified to homogeneity from 4-day old YEPS cultures by a single hydrophobic interaction chromatography step (Figure 2A) using an Octyl Sepharose cartridge (GE Healthcare), as previously reported [32]. Finally, the protein was dialyzed and concentrated, as mentioned above, and kept at $-80^{\circ} \mathrm{C}$ remaining stable in these conditions at least for one year. $9 \mathrm{mg}$ of pure enzyme were obtained from 1L of YEPS medium. The process yield was around $60 \%$ and protein was purified 9.2-fold (Table 1).
SDS-PAGE of the pure recombinant protein from YEPS cultures showed a band at $M_{r} 76,000 \mathrm{Da}$, higher than that described for the native enzyme $(60 \mathrm{kDa})$, and similar to that obtained from BMMY cultures [35]. The heterogeneity of the recombinant protein could be due to different patterns of post-translational modifications. This was confirmed after treatment with Endoglycosidase $\mathrm{H}$ (Figure 2B). The average molecular mass of the recombinant sterol esterase was found to be 74,921 Da by mass spectrometry and this value was used for the determination of its kinetic constants.

The effects of $\mathrm{pH}$ and temperature on enzyme activity and stability were investigated using $3 \mu \mathrm{g} / \mathrm{mL}$ aqueous solutions of the protein. The optimum $\mathrm{pH}$ of the purified recombinant protein was between 7.5 and 8.0, and its optimum temperature at $25^{\circ} \mathrm{C}$, which differs from the value found for the native enzyme (around $60^{\circ} \mathrm{C}$ ). Stability of the native and the recombinant enzyme was similar between $\mathrm{pH} 3.0$ and $\mathrm{pH}$ 9.0, retaining around $50-70 \%$ of their initial activity after $24 \mathrm{~h}$ of incubation. Nevertheless, at $\mathrm{pH} 10.0$ the recombinant enzyme maintained around $50 \%$ of activity while the native one kept less than $20 \%$. 


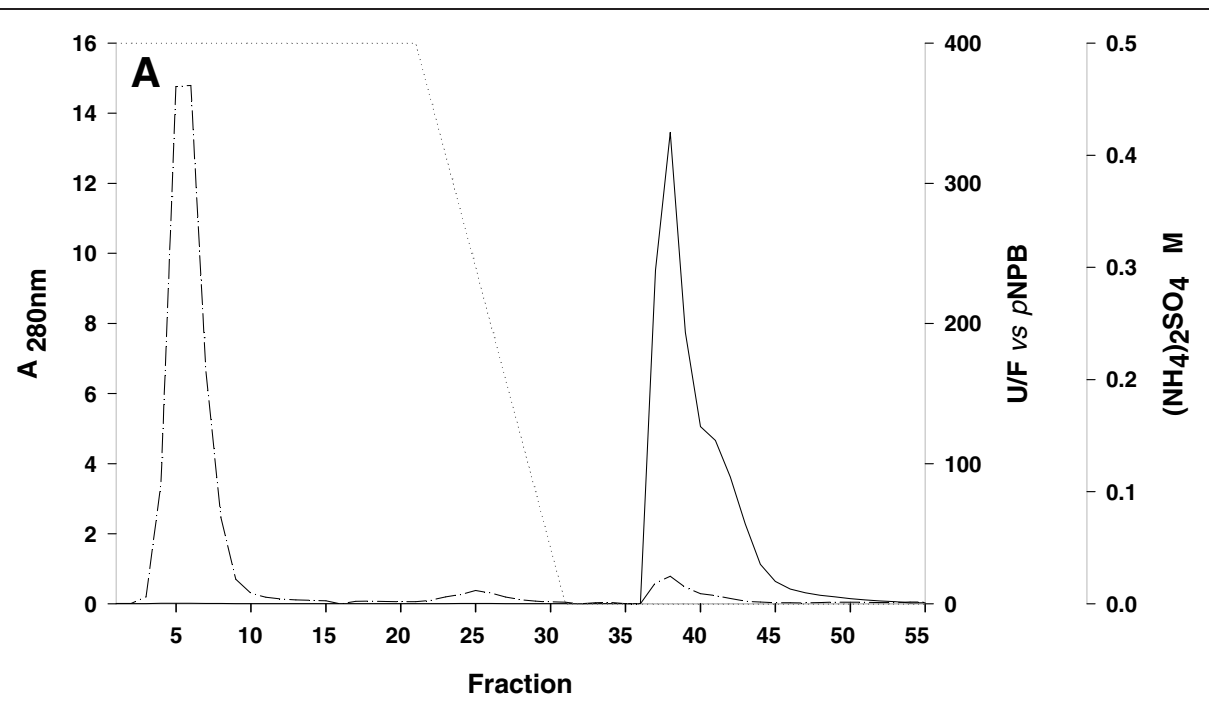

B

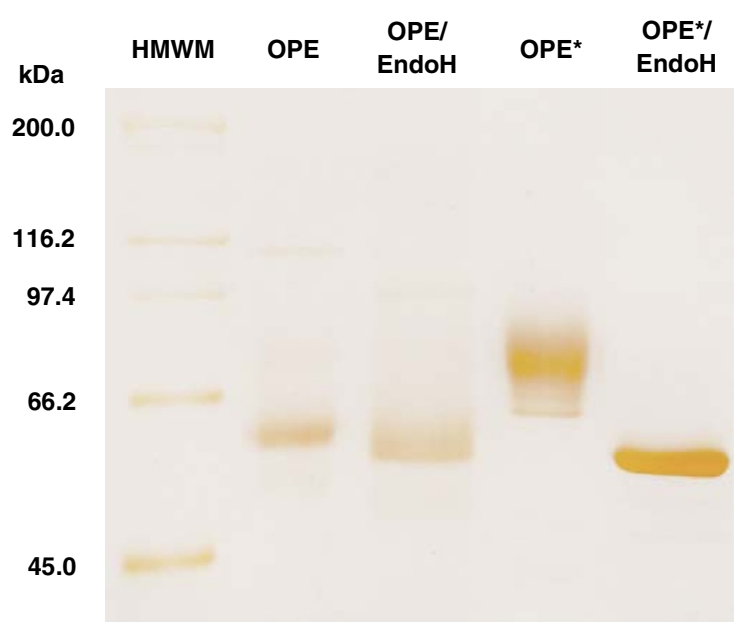

Figure 2 Enzyme purification. Hydrophobic interaction chromatography profile (A): units per fraction (-), A280nm (-.-.---) and gradient (.........). SDS-PAGE for native and recombinant purified proteins before and after treatment with endoglicosidase H (B): High Molecular Weight Marker (HMWM), native O. piceae sterol esterase (OPE), and recombinant enzyme (OPE*). Protein bands are silver stained.

Regarding temperature stability, OPE and $\mathrm{OPE} *$ maintained around $85 \%$ of their initial activity at $4^{\circ} \mathrm{C}$ and $30^{\circ} \mathrm{C}$, after $24 \mathrm{~h}$ of incubation at $\mathrm{pH} 6$. However, the recombinant protein was less stable than the native one at $45^{\circ} \mathrm{C}$ (50\% and 35\%, respectively) and both retained less than

Table 1 Yield and purification grade throughout processing of recombinant enzyme

\begin{tabular}{cccccc}
\hline & $\begin{array}{c}\text { Activity } \\
\text { (Units) }\end{array}$ & $\begin{array}{c}\text { Protein } \\
(\mathbf{m g})\end{array}$ & $\begin{array}{c}\text { Yield } \\
(\%)\end{array}$ & $\begin{array}{c}\text { Ae } \\
(\mathbf{U} / \mathbf{m g})\end{array}$ & $\begin{array}{c}\text { Purification } \\
\text { factor }\end{array}$ \\
\hline Culture liquid & 9539 & 140 & 100 & 68 & 1.0 \\
$\quad \begin{array}{c}\text { Ultrafiltrate } \\
\text { HIC-octyl sepharose }\end{array}$ & 9839 & 89 & 103 & 111 & 1.6 \\
$\begin{array}{c}\text { and removal of Triton } \\
\text { X-100 }\end{array}$ & 5624 & 9 & 59 & 625 & 9.2 \\
\hline
\end{tabular}

Ae: specific activity.
$10 \%$ of their activity at $60^{\circ} \mathrm{C}$. It is interesting to mention that the stability towards $\mathrm{pH}$ and temperature of both proteins depends on their concentration, improving with increasing protein concentrations.

\section{Kinetic characterization}

Reactions were carried out in presence of Genapol X-100 as surfactant due to the low solubility of most of the substrates assayed in aqueous solutions. Protein kinetic parameters were designated as "apparent" (app) as reported for native enzyme [32]. Table 2 summarizes the catalytic properties of the native and the recombinant esterase. Except for $p \mathrm{NPB}$, the recombinant protein showed similar or higher affinity (lower $K_{\mathrm{m}}^{\mathrm{app}}$ values) than the native one, and greater turnover frequency $\left(k_{\text {cat }}^{\mathrm{app}}\right)$ in all cases. Its efficiency $\left(k_{\mathrm{cat}}^{\mathrm{app}} / K_{\mathrm{m}}^{\mathrm{app}}\right)$ increased with the length of the 
Table 2 Apparent kinetic parameters of native and recombinant sterol esterases from 0 . piceae on p-nitrophenol, glycerol and cholesterol esters

\begin{tabular}{|c|c|c|c|c|}
\hline Substrate & $\begin{array}{l}\text { Acyl length and } \\
\text { insaturation(s) }\end{array}$ & $\begin{array}{c}\text { Catalytic } \\
\text { parameters }\end{array}$ & $\begin{array}{l}\text { Native } \\
\text { OPE }^{\mathrm{a}}\end{array}$ & $\begin{array}{c}\text { Recombinant } \\
\text { OPE }\end{array}$ \\
\hline \multirow[t]{3}{*}{$p$-Nitrophenyl butyrate } & C4:0 & $K_{\mathrm{m}}^{\mathrm{app}}$ & $0.27 \pm 0.03$ & $2.33 \pm 0.19$ \\
\hline & & $k_{\mathrm{cat}}^{\mathrm{app}}$ & $44 \pm 2$ & $2533 \pm 55$ \\
\hline & & $k_{\mathrm{cat}}^{\mathrm{app}} / K_{\mathrm{m}}^{\mathrm{app}}$ & $162 \pm 13$ & $1089 \pm 70$ \\
\hline \multirow[t]{3}{*}{ p-Nitrophenyl palmitate } & C16:0 & $K_{\mathrm{m}}^{\mathrm{app}}$ & $0.33 \pm 0.03$ & $0.37 \pm 0.03$ \\
\hline & & $k_{\mathrm{cat}}^{\mathrm{app}}$ & $74 \pm 3$ & $1049 \pm 28$ \\
\hline & & $k_{\mathrm{cat}}^{\mathrm{app}} / K_{\mathrm{m}}^{\mathrm{app}}$ & $224 \pm 12$ & $2875 \pm 212$ \\
\hline \multirow[t]{3}{*}{ Glyceryl tributyrate } & $C 4: 0$ & $K_{\mathrm{m}}^{\mathrm{app}}$ & $9.90 \pm 0.80$ & $5.10 \pm 0.30$ \\
\hline & & $k_{\mathrm{cat}}^{\mathrm{app}}$ & $179 \pm 4$ & $1041 \pm 14$ \\
\hline & & $k_{\mathrm{cat}}^{\mathrm{app}} / K_{\mathrm{m}}^{\mathrm{app}}$ & $18 \pm 1$ & $204 \pm 10$ \\
\hline \multirow[t]{3}{*}{ Glyceryl trioleate } & C18:1 & $K_{m}^{\mathrm{app}}$ & $0.98 \pm 0.08$ & $0.71 \pm 0.09$ \\
\hline & & $k_{\text {cat }}^{\mathrm{app}}$ & $290 \pm 7$ & $1362 \pm 41$ \\
\hline & & $k_{\mathrm{cat}}^{\mathrm{app}} / K_{\mathrm{m}}^{\mathrm{app}}$ & $296 \pm 18$ & $1924 \pm 197$ \\
\hline \multirow[t]{3}{*}{ Cholesteryl butyrate } & $C 4: 0$ & $K_{\mathrm{m}}^{\mathrm{app}}$ & $3.00 \pm 0.50$ & $1.60 \pm 0.20$ \\
\hline & & $k_{\mathrm{cat}}^{\mathrm{app}}$ & $47 \pm 2$ & $212 \pm 7$ \\
\hline & & $k_{\mathrm{cat}}^{\mathrm{app}} / K_{\mathrm{m}}^{\mathrm{app}}$ & $15.6 \pm 1.8$ & $133 \pm 13$ \\
\hline \multirow[t]{3}{*}{ Cholesteryl oleate } & C18:1 & $K_{m}^{\mathrm{app}}$ & $1.00 \pm 0.10$ & $0.69 \pm 0.10$ \\
\hline & & $k_{\mathrm{cat}}^{\mathrm{app}}$ & $138 \pm 4$ & $631 \pm 21$ \\
\hline & & $k_{\mathrm{cat}}^{\mathrm{app}} / K_{\mathrm{m}}^{\mathrm{app}}$ & $138 \pm 9$ & $918 \pm 108$ \\
\hline \multirow[t]{3}{*}{ Cholesteryl linoleate } & C18:2 & $K_{\mathrm{m}}^{\mathrm{app}}$ & $0.99 \pm 0.06$ & $0.71 \pm 0.09$ \\
\hline & & $k_{\text {cat }}^{\mathrm{app}}$ & $150 \pm 3$ & $798 \pm 25$ \\
\hline & & $k_{\mathrm{cat}}^{\mathrm{app}} / K_{\mathrm{m}}^{\mathrm{app}}$ & $152 \pm 6$ & $1132 \pm 123$ \\
\hline
\end{tabular}

Reactions were carried out in the presence of the non-ionic detergent Genapol X-100.

$K_{\mathrm{m}}^{\mathrm{app}}(\mathrm{mM}), k_{\mathrm{cat}}^{\mathrm{app}}\left(\mathrm{s}^{-1}\right)$ and $k_{\mathrm{cat}}^{\mathrm{app}} / K_{\mathrm{m}}^{\mathrm{app}}\left(\mathrm{s}^{-1} \mathrm{mM}^{-1}\right)$. Standard errors are based on the curve fitting using Sigma plot 11.0 software. The $k_{\mathrm{cat}}^{\mathrm{app}} / K_{\mathrm{m}}^{\mathrm{app}}$ standard errors were obtained by fitting the normalized Michaelis-Menten equation as $V=\left(k_{\mathrm{cat}}^{\mathrm{app}} / K_{\mathrm{m}}^{\mathrm{app}}\right)[\mathrm{S}] /\left(1+[\mathrm{S}] / K_{\mathrm{m}}^{\mathrm{app}}\right)$. Kinetics parameters were obtained using the average molecular weight of the non-deglycosylated recombinant protein obtained by mass spectrometry as was previously considered with native one.

a[32].

acyl moiety in the substrate, as well as with the presence of insaturations, as reported elsewhere [32]. The catalytic efficiency of the recombinant enzyme, compared with the native esterase, was about 8-10-fold higher for all the substrates assayed.

Effect of deglycosylation on recombinant enzyme activity The higher degree of $\mathrm{N}$-linked carbohydrate present in the recombinant protein $(28 \%$ against $8 \%$ for the native protein) could contribute to improve its catalytic properties. Both esterases displayed the same $M_{\mathrm{r}}$ after deglycosylation with Endo $\mathrm{H}$ under non-denaturing conditions and did not show significant difference in their activities on $p \mathrm{NPB}$, triolein, and cholesteryl oleate before and after deglycosylation (Figure 3).

\section{Far UV circular dichroism spectra}

Secondary structure of the OPE and $\mathrm{OPE}^{*}$ was analyzed by CD spectroscopy in order to find differences between them which could explain the kinetic results. However, their spectra were similar, with the two typical negative bands at 222 and $209 \mathrm{~nm}$ characteristic of $\alpha$-helix (Figure 4). Analysis of the spectra by the K2d method from Dichroweb [37] resulted in an identical content of $\alpha$-helix (0.46), $\beta$-sheet (0.23), and random coil (0.31) for both proteins.

\section{Methionine oxidation determination}

Oxidation in methionine residues has been previously reported in other proteins expressed in $P$. pastoris [38,39], and could be another factor to explain the improved catalytic properties of the recombinant enzyme. However, amino acid analysis of the recombinant protein revealed the lack of methionine sulfone, oxidized form of methionine (Figure 5).

\section{$\mathrm{N}$-terminal sequencing}

A modified N-terminal sequence was found in the recombinant enzyme (EAEAYVEFTTVNVNYPE) when compared to that from the native one (TTVNVNYPE). This fact can be explained because of the cloning process strategy, which 

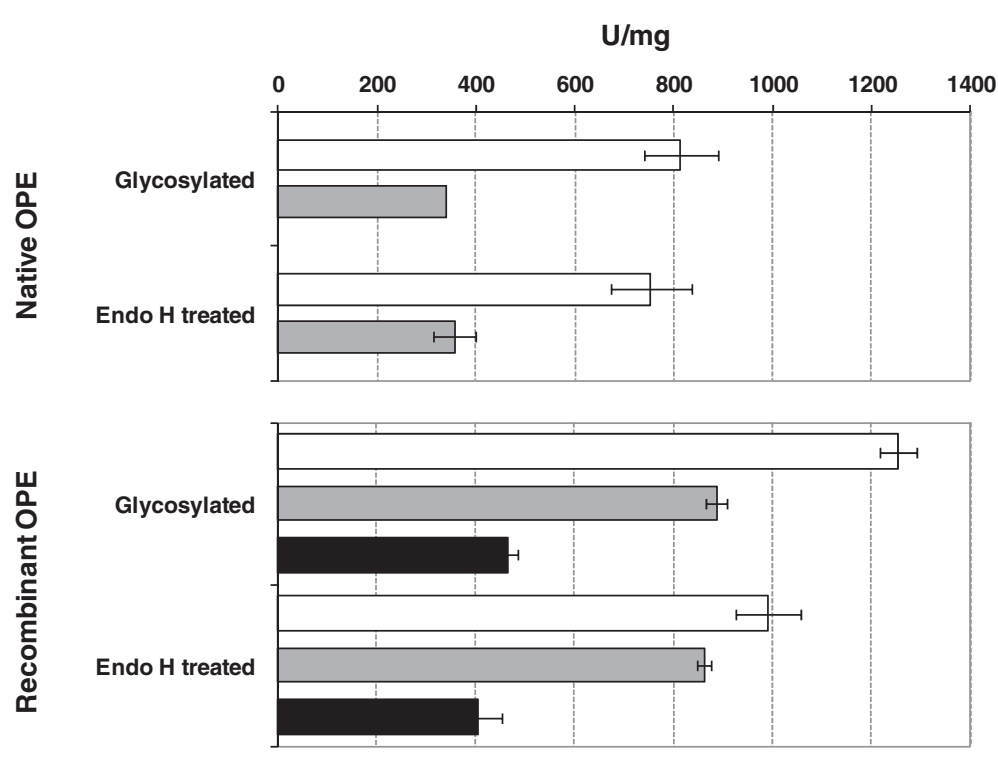

Figure 3 Activity of native and recombinant enzymes before and after the deglycosylation treatment with Endo $\mathbf{H}$. Different substrates were assayed for the analysis: pNPB (white bars), triolein-TO (gray bars), and cholesteryl oleate-CO (black bars). Substrates were used at 5 mM concentration in the presence of Genapol X-100. Conditions are described in experimental section. Data points are the average of at least two different measures. Error bars represent standard deviation.

added 4 amino acid residues (YVEF) belonging to the EcoRI (gaattc) and SnaBI (tacgta) recognition sites in the multiple cloning site (MCS) from pPIC9 vector. On the other hand, the incorrect processing of the pre-propeptide of the $\alpha$ mating factor from S. cerevisiae, used as signal for secretion, by STE13 protease, adds two (EA) or four (EAEA) more

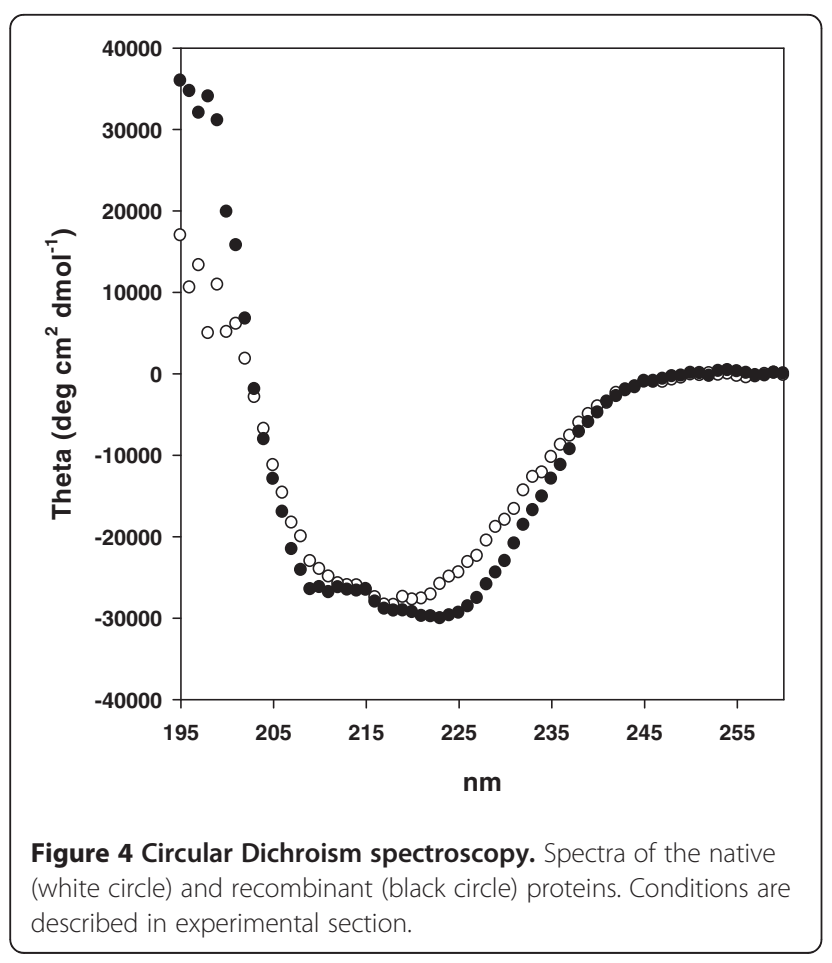

residues to the sequence. Then, the $\mathrm{N}$-terminal sequence of the OPE* contained 6 or 8 additional residues, and both forms were simultaneously found in the purified recombinant protein.

\section{Aggregation behaviour of native and recombinant enzymes}

The aggregation state of both the native and recombinant proteins was studied by analytical ultracentrifugation techniques, comprising sedimentation velocity and equilibrium studies.

Regarding the sedimentation velocity method, the native protein showed a high sedimentation coefficient (Figure 6A) which corresponded to a high molecular mass multi-aggregate in aqueous solution $(25 \mathrm{mM}$ sodium phosphate buffer $\mathrm{pH}$ 7.0), as previously reported [32]. However, under the same conditions, the recombinant protein presented sedimentation coefficients of $4.6 \mathrm{~S}$ and $7.2 \mathrm{~S}$ for the monomeric and dimeric forms, respectively (Figure 6C). When the study was performed in the presence of $1 \%(\mathrm{v} / \mathrm{v})$ Genapol X-100, both proteins showed sedimentation coefficients of $3.3 \mathrm{~S}$ and 3.8S, mainly compatible with the monomeric forms of the native and recombinant protein, respectively (Figure 6B and 6D). These coefficients differ to those measured in water solutions because the detergent affects the floatability of proteins. An additional experiment was carried out, in aqueous solution, with the deglycosylated OPE* obtained after treatment with Endo $\mathrm{H}$ in non-denaturing conditions. In this case, the protein was also found as 


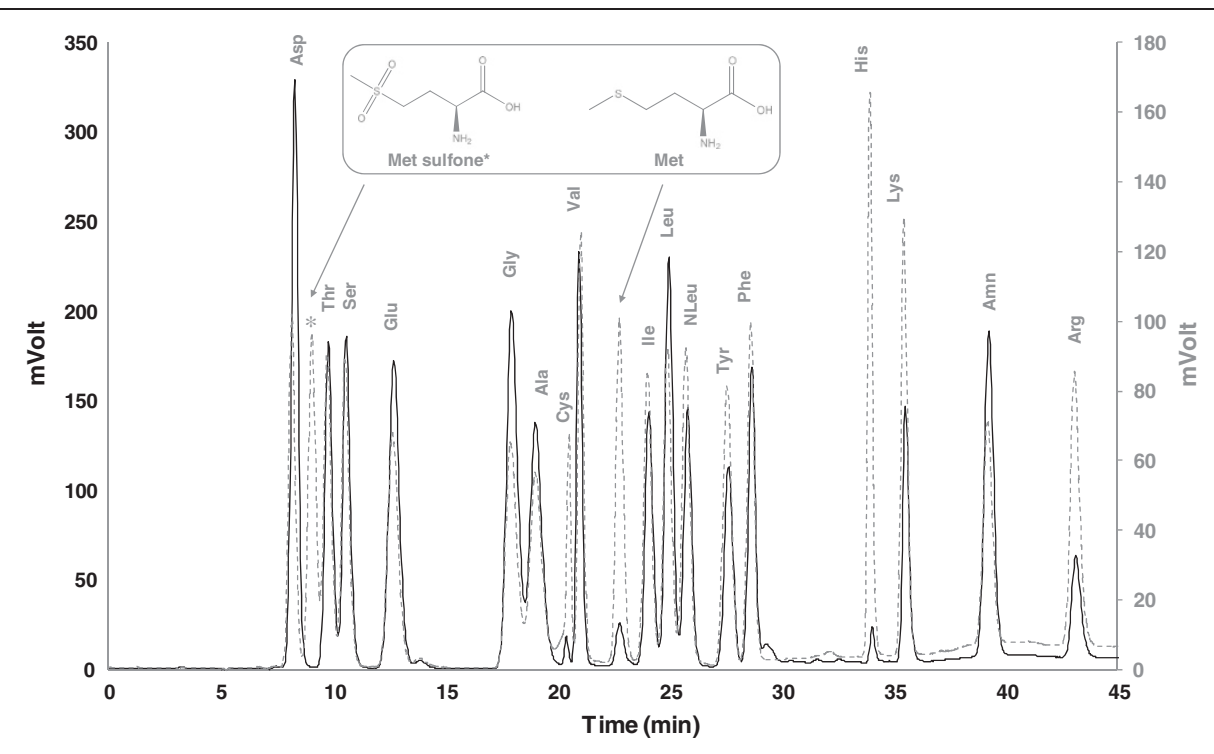

Figure 5 Determination of oxidized methionine residues by amino acid analysis. Chromatograms obtained from a hydrolyzed standard sample in which methionine sulfone was added (----), and from a hydrolyzed sample of recombinant protein (-). Structures of methionine and methionine sulfone are showed in the inner box.

monomeric and dimeric forms, with sedimentation coefficients of $4.2 \mathrm{~S}$ and $6.7 \mathrm{~S}$, slightly lower than those obtained for the glycosylated protein because of the lack of $\mathrm{N}$-glycan attached to asparagine residues.
Equilibrium experiments for glycosylated proteins in aqueous solutions corroborated an average molecular mass of $138 \mathrm{kDa}$ (theoretical v-bar 0.73, being v-bar the partial specific volume) for OPE*, which is compatible
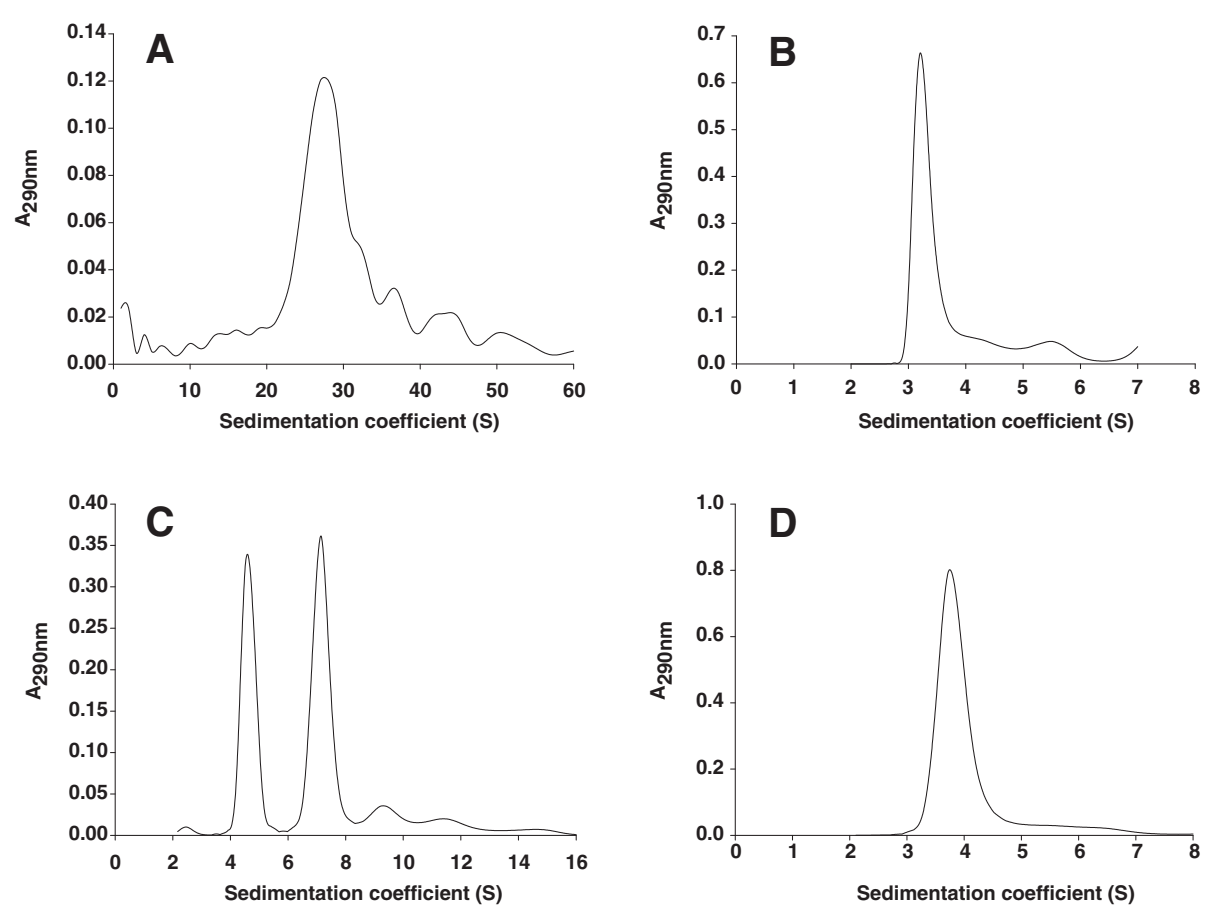

Figure 6 Analytical ultracentrifugation. Sedimentation velocities of the native $(\mathbf{A})$ and recombinant $(\mathbf{C})$ sterol esterases from 0 . piceae in aqueous solution and in the presence of Genapol X-100 (B and D, respectively). Conditions are described in experimental section. 
with the dimer. No results were obtained for the native protein as a consequence of its tendency to form big aggregates, which prevents this kind of study. When a surfactant was employed, average molecular masses were $45 \mathrm{kDa}$ (theoretical v-bar 0.73) and $56 \mathrm{kDa}$ (theoretical v-bar 0.73) for OPE and OPE*, respectively (lower than those expected because of Genapol X-100, although compatible with the monomeric form). Concerning the deglycosylated recombinant protein, an average molecular mass of $109 \mathrm{kDa}$ (theoretical v-bar 0.74) was obtained in aqueous solution. This can be explained from the coexistence of a mixture of molecular species, in contrast with the $47.5 \mathrm{kDa}$ (theoretical v-bar 0.74) obtained for this sample in presence of the detergent, compatible with the monomeric form (data not shown).

\section{Discussion}

Several advantages of using $P$. pastoris as biofactory for the production of the recombinant protein have already been mentioned. An additional reason to choose this system to express the $O$. piceae sterol esterase was that other fungal lipases have been successfully expressed in this yeast, such as the different isoenzymes (Lip1-Lip5) from C. rugosa $[8,10,40-44]$ and G. candidum $[45,46]$, as well as the sterol esterase from $M$. albomyces [15].

The screening to select the clones of $P$. pastoris with sterol esterase activity was carried out by using a simple plate activity assay [47] based on the hydrolysis of tributyrin in MM medium, which showed clear halos in the positive transformants. Initially, five positive clones were selected for the production of the sterol esterase in $1 \mathrm{~L} \mathrm{Er}$ lenmeyer flask containing different volumes of BMMY liquid medium. In any case, all clones secreted higher activity levels than those attained with $O$. piceae. However, the highest levels (up to $18 \mathrm{U} / \mathrm{mL}$ ) were obtained when a lower volume of culture medium was used [35] because of the increase in the oxygen transfer rate. This is one of the different strategies previously proposed to facilitate oxygen transfer in Erlenmeyer flask cultures [28,31].

On the other hand, since the production of recombinant proteins in P. pastoris is closely connected to growth yields, the use of different carbon sources on biomass production, and so on the expression of the recombinant protein was studied. As methanol is a poor energetic substrate yielding in theory only 6 ATP molecules, both in assimilation and dissimilation pathways $[48,49]$, the biomass production in media with methanol as the sole carbon source was lower than those obtained in media with sorbitol. In accordance with this, the biomass was lower for the selected $P$. pastoris $\mathrm{Mut}^{+}$transformant growing in media with only methanol (MM, BMM, and BMMY) than in a medium with an alternative carbon source like sorbitol (YEPS), which do not repress $A O X 1$ promoter [50]. Consequently, the greatest activity levels were obtained in YEPS medium, being 3- and 32-fold higher than in BMMY and BMM media, respectively in terms of maximal activity. The performance of the production in YEPS medium, according to generated biomass, was higher than in BMMY and BMM (2- and 15- fold, respectively) and much higher than with $\mathrm{MM}$ (127-fold). The use of either complex or unbuffered media could contribute to decrease the effect of proteases during growing of $P$. pastoris. In the first case, yeast extract and peptone not only improve the growth of the yeast, but also can be substrates for proteases and could suppress their expression when nitrogen is limited $[28,51]$. In the second case, the growth of the yeast causes a fall in $\mathrm{pH}$, favouring protease inactivation [36]. All these facts could explain the better activity levels found in BMMY medium as compared with BMM medium, and the very low activity detected in MM media. These results agree with previous reports describing higher activity levels of the recombinant cinnamoyl esterase from Aspergillus niger expressed in the yeast when buffered complex media were used [52]. Nevertheless, low activity levels of recombinant $M$. albomyces sterol esterase have been obtained in these culture conditions [15]. On the other hand, and also agreeing with our data, G. candidum lipase activity was not detected in cultures in MM medium [46], probably due to a pronounced decrease in $\mathrm{pH}$ with time (around 2), which would cause the denaturalization of the enzyme.

The recombinant enzyme was purified from YEPS medium in a single chromatographic step, with a purification factor higher than that obtained for the native enzyme [32]. LIP3 from C. rugosa was purified with a similar procedure, but yielding lower amounts of protein [8].

The purified enzyme can work in a wide $\mathrm{pH}$ range keeping more than $50 \%$ of its initial activity, as has also been reported for recombinant LIP3 [8], and it is thermostable at $4^{\circ} \mathrm{C}$ and $30^{\circ} \mathrm{C}$ for 24 hours in the assayed conditions. In any case, comparing the native and recombinant proteins, $\mathrm{OPE}^{*}$ showed higher stability at very alkaline $\mathrm{pHs}$ and lower optimum temperature than OPE, which could be advantageous for its industrial application.

The existence of different post-translational modifications was considered in order to explain the observed changes, not only in the optimum temperature but also in the kinetic parameters of the recombinant enzyme. Regarding glycosylation, it has been described that long outer chains can potentially interfere with the folding and function of a foreign protein [29]. However, dichroism spectroscopy experiments (Figure 4) indicated that the recombinant protein was not misfolded, and an identical secondary structure was deduced for both sterol esterases. In addition, $\mathrm{N}$-linked carbohydrates did not seem to be needed for maintaining the hydrolytic activity of these proteins, as deduced from deglycosylation 
experiments (Figure 3). Similarly, lipase B from Candida antarctica [53] and LIP4 from C. rugosa [43] maintained comparable kinetic properties after their expression in $E$. coli, although the glycosylated form of LIP4 produced in $P$. pastoris had higher thermal stability.

On the other hand, the partial oxidation of methionine residues during heterologous expression of proteins in $P$. pastoris has been reported [38,39]. Peroxisome environment in $P$. pastoris is highly oxidative and oxidation of sensitive residues could occur when hydrogen peroxide, produced during methanol metabolism, is released from peroxisomes to the culture medium after minimal cell lysis [39]. The sequence of the O. piceae sterol esterase contains 5 oxidizable methionine residues, one of them located in the surroundings of the substrate binding site [35]. However, amino acid analysis of the recombinant $O$. piceae sterol esterase suggested that this is not the reason for its improved catalytic properties, since no methionine sulfone residues were found (Figure 5).

Secretion is the preferred approach for heterologous protein production due to the ease of product recovery [54]. Furthermore, the secreted recombinant protein in $P$. pastoris constitutes the vast majority of total protein in the medium because the yeast secretes low levels of endogenous proteins [29]. However, the high level of expression from $\mathrm{P}_{A O X 1}$ may overwhelm the post-translational machinery of the cell causing an unprocessed foreign protein [29]. The bad processing of the pre-propeptide of the $\alpha$-mating factor can be explained by the formation of tertiary structures during the expression of a foreign protein that could protect cleavage sites from KEX2 and STE13 proteases [29]. In addition STE13, which cleaves EA repetitions, is a minor protein in the cell and it would not be able to process correctly an overexpressed protein [55]. Sequencing of the N-terminal region of the recombinant $O$. piceae esterase disclosed a wrong processing of the protein, since its $\mathrm{N}$-terminus contained 6 or 8 additional residues from the secretion signal and the vector. This modification at the $\mathrm{N}$-terminal end seems to influence some properties of the recombinant protein such as its aggregation state, as shown by analytical ultracentrifugation (Figure 6). While the native enzyme forms big aggregates in water solution [32], as reported for the M. albomyces sterol esterase [21], the recombinant enzyme remained as a mixture of monomeric and dimeric forms (even at $200 \mu \mathrm{g} / \mathrm{mL}$ ). This behaviour could be the ultimate reason responsible for the improved catalytic properties of the recombinant enzyme. A wrong processing of the $\alpha$-mating factor pre-propeptide has also been described in other proteins expressed in $P$. pastoris, such as the feruloyl esterase from Talaromyces stipitatus [56], the xylanase from Thermomyces lanuginosus [57], as well as the lipases from C. antarctica [53] and Candida parasilopsis [58], but the catalytic properties of these recombinant proteins were not affected. This wrong processing has been reported even in S. cerevisiae [59].

Esterases and lipases form pseudo-quaternary structures easily in aqueous solution. Multimeric forms have been described for the $M$. albomyces sterol esterase in the absence of detergent [21] although, at low concentrations, tetrameric forms have been reported for the native protein, and dimeric structures for the recombinant variant $[15,60]$. This tendency to form multimolecular aggregates has also been reported in the lipase from $C$. parapsilosis [58] and in the sterol esterases from Streptomyces species [6]. In addition, recombinant C. rugosa LIP2, expressed in $P$. pastoris, resulted in an aggregated, inactivated form of the protein, and only after diaultrafiltration lipolytic activity was recovered [10]. Monomolecular forms from $C$. rugosa, Humicola lanuginosa (synonym T. lanuginosus), and Mucor miehei lipases were found only at low enzyme concentrations and in the presence of detergents. So it is difficult to find only the monomolecular form of lipasetype enzymes since it can only be achieved by mixing the enzyme solution with a detergent [61].

Lipases display different functional properties in their monomeric or aggregated forms [61]. In general, it seems that multimolecular forms exhibit lower specific activity and higher stability to $\mathrm{pH}$ and temperature than the monomeric proteins, although controversial data have been published for C. rugosa lipase [62]. For instance, enzymes from M. albomyces and Streptomyces sp. increased their activity in the presence of a detergent, where proteins probably tend to be in their monomolecular form $[6,21]$. However, in the case of $O$. piceae sterol esterase, neither activation nor inactivation of the enzyme (native or recombinant) has been reported in the presence of $0.2 \%$ Triton X-100 (used in the purification of these proteins), although above this concentration a decrease in their activity was observed (data not shown) as reported for the lipase BTL2 from Bacillus thermocatenulatus [63]. The use of Genapol X100 , which is indispensable in reactions involving longchain triglycerides or fattyacid cholesterol esters in order to solubilise them, is detrimental for enzyme activity on $p$ NPB since it acts as a competitive inhibitor for this short chain substrate [32]. In any case, as we report here, the use of detergents favour the monomeric form of the protein.

In accordance with previous works [61], when a concentrated aqueous solution of the recombinant enzyme was maintained during $16 \mathrm{~h}$ at $37^{\circ} \mathrm{C}$ no significant loss of activity was found. On the contrary, if this solution is diluted and the resulting solution incubated under the same conditions, an appreciable amount of activity was lost.

The high overall content in hydrophobic amino acid residues (38\%) of the native enzyme could explain its tendency to form aggregates, as has been suggested for lipase BTL1 from B. thermocatenulatus [63]. However, the modification at the $\mathrm{N}$-terminal end of the recombinant protein 
expressed in P. pastoris, by the addition of 6-8 extra amino acid residues from pPIC9 vector, used for protein expression, and the inefficient processing of the $\alpha$-mating factor pre-propeptide, used for secretion, affected the aggregation state of the protein, as was confirmed by analytical ultracentrifugation experiments with deglycosylated recombinant enzyme.

Usually, a bad processing has no effect on recombinant protein activity, such as in G. candidum [46], Yarrowia lipolytica [64], and C. parasilopsis lipases [58]. An improvement of catalytic properties [65-69] and stability $[8,42]$ of some recombinant and native enzymes has been previously reported, speculating on the basis of different glycosylation degree, $\mathrm{N}$-terminal modification or aminoacid substitution (due to a preferential codon use in P. pastoris respect to natural host) [42]. However, to the best of our knowledge, the results presented in this paper constitute the first experimental report of an improvement of the solubility and kinetic constants of the enzyme, as a consequence of its $\mathrm{N}$ terminal modification.

\section{Conclusions}

The selection of the expression system is important in order to guarantee that a bioactive recombinant protein is produced with good yield. In this context, $P$. pastoris is a well-characterized system, which offers different possibilities for expression and is used in well-studied bioprocesses. So, it could be considered as an optimal biofactory for the production of sterol esterases, lipases, and esterases. This yeast resulted to be an excellent system for the heterologous production of recombinant sterol esterase yielding higher protein levels than those obtained with $O$. piceae. The recombinant protein showed different optimum temperature and improved catalytic properties probably due to its modified N-terminus, which must have caused changes in its hydrophobicity, altering its aggregation behaviour, and affecting positively its hydrolysis efficiency for all the substrates assayed.

\section{Competing interests}

The authors declare that there are no competing interests.

\section{Authors' contributions \\ VBC performed the DNA cloning and microbial transformations, the activity assays, characterization of the enzyme, data analysis, and drafted the manuscript. FJP designed the experiments for the kinetic characterization of the enzymes. MJM designed and coordinated the study and helped to draft the manuscript. All authors read and approved the submission of the manuscript.}

\section{Acknowledgements}

This work has been financed by the Spanish projects Bio2009-08446, and S2009AMB-1480. Authors thank A. Prieto and G. Giménez, both from Centro de Investigaciones Biológicas, for their help in the discussion of the results and for the analysis of circular dichroism data with $\mathrm{K} 2 \mathrm{~d}$ method from Dichroweb, respectively, as well as CIB facilities (Protein Chemistry, Proteomics, and Analytical Ultracentrifugation) for their technical support. V. Barba Cedillo thanks Spanish MICINN the financial support from FPU program.

\section{Author details}

${ }^{1}$ Centro de Investigaciones Biológicas (CIB), Spanish National Research Council (CSIC), Ramiro de Maeztu 9, Madrid 28040, Spain. ${ }^{2}$ Instituto de Catálisis y Petroleoquímica, Spanish National Research Council (CSIC), Marie Curie 2, Madrid 28049, Spain.

Received: 13 December 2011 Accepted: 2 March 2012 Published: 7 June 2012

\section{References}

1. Brown AW, Hang J, Dussault PH, Carr TP: Plant sterol and stanol substrate specificity of pancreatic cholesterol esterase. I Nutr Biochem 2010, 21:736-740.

2. Ikeda I, Matsuoka R, Hamada T, Mitsui K, Imabayashi S, Uchino A, et al: Cholesterol esterase accelerates intestinal cholesterol absorption. Biochimica et Biophysica Acta (BBA) - General Subjects 2002, 1571:34-44.

3. Loomes KM, Senior $\mathrm{HEJ}$ : Bile salt activation of human cholesterol esterase does not require protein dimerisation. FEBS Lett 1997, 405:369-372.

4. Sugihara A, Shimada Y, Nomura A, Terai T, Imayasu M, Nagai Y, et al: Purification and characterization of a novel cholesterol esterase from Pseudomonas aeruginosa, with its application to cleaning lipid-stained contact lenses. Biosci Biotechnol Biochem 2002, 66:2347-2355.

5. Xiang H, Takaya N, Hoshino T: Novel cholesterol esterase secreted by Streptomyces persists during aqueous long-term storage. J Biosci Bioeng 2006, 101:19-25.

6. Xiang H, Masuo S, Hoshino T, Takaya N: Novel family of cholesterol esterases produced by actinomycetes bacteria. Biochimica et Biophysica Acta (BBA) - Proteins \& Proteomics 2007, 1774:112-120.

7. Benjamin S, Pandey A: Candida rugosa lipases: molecular biology and versatility in biotechnology. Yeast 1998, 14:1069-1087.

8. Chang SW, Lee GC, Shaw JF: Efficient production of active recombinant Candida rugosa LIP3 lipase in Pichia pastoris and biochemical characterization of purified enzyme. J Agric Food Chem 2006, 54:5831-5838.

9. Ferrer P, Montesinos JL, Valero F, Solá C: Production of native and recombinant lipases by Candida rugosa - a review. Appl Biochem Biotechnol 2001, 95:221-255.

10. Ferrer P, Alarcón M, Ramón R, Benaiges MD, Valero F: Recombinant Candida rugosa LIP2 expression in Pichia pastoris under the control of the AOX1 promoter. Biochem Eng J 2009, 46:271-277.

11. López N, Pernas MA, Pastrana LM, Sánchez A, Valero F, Rúa ML: Reactivity of pure Candida rugosa lipase isoenzymes (Lip1, Lip2, and Lip3) in aqueous and organic media. Influence of the isoenzymatic profile on the lipase performance in organic media. Biotechnol Prog 2004, 20:65-73.

12. Mancheño JM, Pernas MA, Martínez MJ, Ochoa B, Rúa ML, Hermoso JA Structural insiesterase behaviour in the/esterase behaviour in the Candida rugosa lipases family: crystal structure of the lipase 2 isoenzyme at $1.97 \AA$ A resolution. J Mol Biol 2003, 332:1059-1069.

13. Tenkanen M, Kontkanen $H$, Isoniemi $R$, Spetz P, Holmbom B: Hydrolysis of steryl esters by a lipase (Lip 3) from Candida rugosa. Appl Microbiol Biotechnol 2002, 60:120-127.

14. Yen CC, Malmis CC, Lee GC, Lee LC, Shaw JF: Site-specific saturation mutagenesis on residues 132 and 450 of Candida rugosa LIP2 enhances catalytic efficiency and alters substrate specificity in various chain lengths of triglycerides and esters. J Agric Food Chem 2010, 58:10899-10905.

15. Kontkanen H, Reinikainen T, Saloheimo M: Cloning and expression of a Melanocarpus albomyces steryl esterase gene in Pichia pastoris and Trichoderma reesei. Biotechnol Bioeng 2006, 94:407-415.

16. Maeda A, Mizuno T, Bunya M, Sugihara S, Nakayama D, Tsunasawa S, et al: Characterization of novel cholesterol esterase from Trichoderma sp AS59 with high ability to synthesize steryl esters. J Biosci Bioeng 2008, 105:341-349.

17. Nardini M, Dijkstra BW: $\alpha / \beta$ hydrolase fold enzymes: the family keeps growing. Curr Opin Struct Biol 1999, 9:732-737.

18. Du L, Huo Y, Ge F, Yu J, Li W, Cheng G, et al: Purification and characterization of novel extracellular cholesterol esterase from Acinetobacter sp. J Basic Microbiol 2010, 50:S30-S36.

19. Hyun J, Steinberg M, Treadwell CR, Vahouny GV: Cholesterol esterase. A polymeric enzyme. Biochem Biophys Res Commun 1971, 44:819-825

20. Pernas MA, López C, Rúa ML, Hermoso J: Influence of the conformational flexibility on the kinetics and dimerisation process of two Candida rugosa lipase isoenzymes. FEBS Lett 2001, 501:87-91. 
21. Kontkanen $\mathrm{H}$, Tenkanen $\mathrm{M}$, Reinikainen $\mathrm{T}$ : Purification and characterisation of a novel steryl esterase from Melanocarpus albomyces. Enzyme Microb Technol 2006, 39:265-273.

22. Reis P, Holmberg K, Watzke H, Leser ME, Miller R: Lipases at interfaces: a review. Adv Colloid Interface Sci 2009, 147-148:237-250.

23. Svendsen A: Lipase protein engineering. Biochimica et Biophysica Acta (BBA) - Protein Structure and Molecular Enzymology 2000, 1543:223-238.

24. Palma MB, Pinto AL, Gombert AK, Seitz KH, Kivatinitz SC, Castilho LR, et al: Lipase production by Penicillium restrictum using solid waste of industrial babassu oil production as substrate. Appl Biochem Biotechnol 2000, 84-86:1137-1145.

25. Schmidt-Dannert C: Recombinant microbial lipases for biotechnological applications. Bioorg Med Chem 1999, 7:2123-2130.

26. Faber KN, Harder W, Ab G, Veenhuis M: Review: methylotrophic yeast as factories for the production of foreign proteins. Yeast 1995, 11:1331-1344.

27. Domínguez A, Fermiñán E, Sánchez M, González FJ, Pérez-Campo FM, García S, et al: Non-conventional yeasts as hosts for heterologous protein production. Int Microbiol 1998, 1:131-142.

28. Macauley-Patrick S, Fazenda ML, McNeil B, Harvey LM: Heterologous protein production using the Pichia pastoris expression system. Yeast 2005, 22:249-270.

29. Cereghino $J$ L, Cregg JM: Heterologous protein expression in the methylotrophic yeast Pichia pastoris. FEMS Microbiol Rev 2000, 24:45-66.

30. De Schutter K, Lin YC, Tiels P, Van Hecke A, Glinka S, Weber-Lehmann J, et al: Genome sequence of the recombinant protein production host Pichia pastoris. Nat Biotechnol 2009, 27:561-566.

31. Rosenfeld SA: Use of Pichia pastoris for expression of recombinant proteins. In Methods in Enzymology. Expression of Recombinant Genes in Eukaryotic Systems, Volume 306. Edited by Joseph CG. San Diego, California: Academic Press; 1999:154-169.

32. Calero-Rueda O, Plou FJ, Ballesteros A, Martínez AT, Martínez MJ: Production, isolation and characterization of a sterol esterase from Ophiostoma piceae. Biochimica et Biophysica Acta (BBA) - Proteins \& Proteomics 2002, 1599(1-2):28-35.

33. Calero-Rueda O, Gutiérrez A, del Río JC, Muñoz MC, Plou FJ, Martínez AT, et al: Method for the enzymatic control of pitch deposits formed during paper pulp production using an esterase that hydrolyses triglycerides and sterol esters.: International patent WO 02/075045 A1R1; 2002:1-28.

34. Calero-Rueda O, Gutiérrez A, del Río JC, Prieto A, Plou FJ, Ballesteros A, et al: Hydrolysis of sterol esters by an esterase from Ophiostoma piceae: application for pitch control in pulping of Eucalyptus globulus wood. Int $J$ Biotechnol 2004, 6:367-375.

35. Calero-Rueda O, Barba V, Rodríguez E, Plou F, Martínez AT, Martínez MJ: Study of a sterol esterase secreted by Ophiostoma piceae: sequence, model and biochemical properties. Biochimica et Biophysica Acta (BBA) - Proteins \& Proteomics 2009, 1794:1099-1106.

36. Invitrogen ${ }^{\mathrm{T}}$ : A manual of methods for expression of recombinant proteins in Pichia pastoris, Catalog no.: K1710-01 edn; 2002.

37. Lobley A, Whitmore L, Wallace BA: Dichroweb: an interactive website for the analysis of protein secondary structure from circular dichroism spectra. Bioinformatics 2002, 18:211-212

38. Barral P, Tejera ML, Treviño MA, Batanero E, Villalba M, Bruix M, et al: Recombinant expression of Ole e 6, a Cys-enriched pollen allergen, in Pichia pastoris yeast: detection of partial oxidation of methionine by NMR. Protein Expr Purif 2004, 37:336-343.

39. Shapiro RI, Wen D, Levesque M, Hronowski X, Gill A, Garber EA, et al: Expression of Sonic hedgehog-Fc fusion protein in Pichia pastoris. Identification and control of post-translational, chemical, and proteolytic modifications. Protein Expr Purif 2003, 29:272-283.

40. Brocca S, Schmidt-Dannert C, Lotti M, Alberghina L, Schmid RD: Design, total synthesis, and functional overexpression of the Candida rugosa lip 1 gene coding for a major industrial lipase. Protein Sci 1998, 7:1415-1422.

41. Chang SW, Lee GC, Shaw JF: Codon optimization of Candida rugosa lip1 gene for improving expression in Pichia pastoris and biochemical characterization of the purified recombinant LIP1 lipase. J Agric Food Chem 2006, 54:815-822.

42. Lee GC, Lee LC, Sava V, Shaw JF: Multiple mutagenesis of non-universal serine codons of the Candida rugosa lip2 gene and biochemical characterization of purified recombinant LIP2 lipase overexpressed in Pichia pastoris. Biochem J 2002, 366:603-611.

43. Tang SJ, Shaw JF, Sun KH, Sun GH, Chang TY, Lin CK, et al: Recombinant expression and characterization of the Candida rugosa LIP4 lipase in
Pichia pastoris: comparison of glycosylation, activity, and stability. Arch Biochem Biophys 2001, 387:93-98.

44. Lee LC, Yen CC, Malmis CC, Chen LF, Chen JC, Lee GC, et al: Characterization of codon-optimized recombinant Candida rugosa lipase 5 (LIP5). J Agric Food Chem 2011, 59:10693-10698.

45. Catoni E, Schmidt-Dannert C, Brocca S, Schmid RD: Overexpression of lipase A and B of Geotrichum candidum in Pichia pastoris: high-level production and some properties of functional expressed lipase $B$. Biotechnol Tech 1997, 11:689-695

46. Holmquist M, Tessier DC, Cygler M: High-level production of recombinant Geotrichum candidum lipases in yeast Pichia pastoris. Protein Expr Purif 1997, 11:35-40.

47. Cregg JM, Tolstorukov I, Kusari A, Sunga J, Madden K, Chappell T: Expression in the yeast Pichia pastoris. In Methods in Enzymology. Guide to protein purification, Volume 463. Edited by Richard Burgess, Deutscher Murray P. San Diego, California: Academic Press; 2009:169-189.

48. Jahic M, Rotticci-Mulder JC, Martinelle M, Hult K, Enfors SO: Modeling of growth and energy metabolism of Pichia pastoris producing a fusion protein. Bioprocess Biosyst Eng 2002, 24:385-393.

49. Ren HT, Yuan JQ, Bellgardt K-H: Macrokinetic model for methylotrophic Pichia pastoris based on stoichiometric balance. J Biotechnol 2003, 106:53-68.

50. Inan M, Meagher MM: Non-repressing carbon sources for alcohol oxidase (AOX1) promoter of Pichia pastoris. J Biosci Bioeng 2001, 92:585-589.

51. Daly R, Hearn MTW: Expression of heterologous proteins in Pichia pastoris: a useful experimental tool in protein engineering and production. J Mol Recognit 2005, 18:119-138.

52. Juge N, Williamson G, Puigserver A, Cummings NJ, Connerton IF, Faulds CB: High-level production of recombinant Aspergillus niger cinnamoyl esterase (FAEA) in the methylotrophic yeast Pichia pastoris. FEMS Yeast Res 2001, 1:127-132.

53. Larsen MW, Bornscheuer UT, Hult K: Expression of Candida antarctica lipase B in Pichia pastoris and various Escherichia coli systems. Protein Expr Purif 2008, 62:90-97.

54. Sreekrishna K, Brankamp RG, Kropp KE, Blankenship DT, Tsay JT, Smith PL, et al Strategies for optimal synthesis and secretion of heterologous proteins in the methylotrophic yeast Pichia pastoris. Gene 1997, 190:55-62.

55. Brake AJ: Secretion of heterologous proteins directed by the yeast afactor leader. In Yeast Genetic Engineering, Biotechnology series 1989:269-280.

56. Crepin VF, Faulds CB, Connerton IF: Production and characterization of the Talaromyces stipitatus feruloyl esterase FAEC in Pichia pastoris: identification of the nucleophilic serine. Protein Expr Purif 2003, 29:176-184.

57. Damaso MCT, Almeida MS, Kurtenbach E, Martins OB, Pereira N Jr, Andrade CMMC, et al: Optimized expression of a thermostable xylanase from Thermomyces lanuginosus in Pichia pastoris. Appl Environ Microbiol 2003, 69:6064-6072.

58. Brunel L, Neugnot V, Landucci L, Boze WN, Moulin G, Bigey F, et al: High-level expression of Candida parapsilosis lipase/acyltransferase in Pichia pastoris. J Biotechnol 2004, 111:41-50.

59. Romanos MA, Scorer CA, Clare JJ: Foreign gene expression in yeast: a review. Yeast 1992, 8:423-488.

60. Kontkanen H, Saloheimo M, Pere J, Miettinen-Oinonen A, Reinikainen T: Characterization of Melanocarpus albomyces steryl esterase produced in Trichoderma reesei and modification of fibre products with the enzyme. Appl Microbiol Biotechnol 2006, 72:696-704.

61. Palomo JM, Fuentes M, Fernández-Lorente G, Mateo C, Guisán JM, Fernández-Lafuente R: General trend of lipase to self-assemble giving bimolecular aggregates greatly modifies the enzyme functionality. Biomacromolecules 2003, 4:1-6.

62. Liou YC, Marangoni AG, Yada RY: Aggregation behaviour of Candida rugosa lipase. Food Res Int 1998, 31:243-248.

63. Rúa ML, Schmidt-Dannert C, Wahl S, Sprauer A, Schmid RD: Thermoalkalophilic lipase of Bacillus thermocatenulatus. Large-scale production, purification and properties: aggregation behaviour and its effect on activity. J Biotechnol 1997, 56:89-102.

64. Song $H T$, Jiang $Z B, M a L X$ : Expression and purification of two lipases from Yarrowia lipolytica AS 2.1216. Protein Expr Purif 2006, 47:393-397.

65. Yu XW, Wang $L L, X u$ Y: Rhizopus chinensis lipase: gene cloning, expression in Pichia pastoris and properties. J Mol Catal B: Enzym 2009, 57:304-311.

66. Mandrich L, Merone L, Pezzullo M, Cipolla L, Nicotra F, Rossi M, et al: Role of the $\mathrm{N}$-terminus in enzyme activity, stability and specificity in 
thermophilic esterases belonging to the HSL family. J Mol Biol 2005,

345:501-512.

67. Niu W, Li Z, Tan T: Secretion of pro- and mature Rhizopus arrhizus lipases by Pichia pastoris and properties of the proteins. Mol Biotechnol 2006, 32:73-81.

68. Peña-Montes C, Lange S, Castro-Ochoa D, Ruiz-Noria K, Cruz-García F,

Schmid R, et al: Differences in biocatalytic behaviour between two variants of Stcl esterase from Aspergillus nidulans and its potential use in biocatalysis. J Mol Catal B: Enzym 2009, 61:225-234.

69. Sayari A, Frikha F, Miled N, Mtibaa H, Ali YB, Verger R, et al: N-terminal peptide of Rhizopus oryzae lipase is important for its catalytic properties. FEBS Lett 2005, 579:976-982.

doi:10.1186/1475-2859-11-73

Cite this article as: Barba Cedillo et al:: Recombinant sterol esterase from Ophiostoma piceae: an improved biocatalyst expressed in Pichia pastoris. Microbial Cell Factories 2012 11:73.

\section{Submit your next manuscript to BioMed Central and take full advantage of:}

- Convenient online submission

- Thorough peer review

- No space constraints or color figure charges

- Immediate publication on acceptance

- Inclusion in PubMed, CAS, Scopus and Google Scholar

- Research which is freely available for redistribution 